\title{
PROVINCIAL-FEDERAL CO-OPERATION
}

\author{
D. E. LEWIS, Q.C.* \\ Outlining The Problem
}

The purpose of this paper is to discuss federal-provincial co-operation from the practical point of view in the light of the law as it appears today. The confusion that now exists in the law when related to certain phases of the oil and gas industry can very adversely affect the future of the industry. Business men, in intelligently planning for the future, are handicapped if there is not stability in legislation and legislative control; otherwise, pre-decision of economics, transportation policies, financing, producing and marketing concepts is meaningless or impossible. Predictions in law are difficult but necessary in our economy.

The Honourable Vincent C. MacDonald stated in his lecture at Osgoode Hall in 1960.'

The art of the lawyer has been said to be that of predicting the decisions of the future from the principles of past decisions in reliance on the doctrine of stare decisis. But as Justice Douglas has warned us in terms very applicable in constitutional cases: "The difficulty is to estimate what effect a slightly different shade of facts will have, and to predict the speed in a changing stream of law;

(for) the predictions are indeed, appraisals of a host of imponderables'.

He goes on to state that the predicability of statutory validity in Canada is extremely difficult for three reasons:

1. The relatively small number of decisions upon which to base our premises with inconsistencies and diverse methods of approach;

2. The little effect that stare decisis has on Canadian constitutional cases; and

3. The wide area of discretion and choices open or frec from binding authority meaning the ultimate decision depends to an unusual extent upon qualities personal to the judge of last resort.

The seminar discussions have revealed the many problems confronting the oil and gas industry in Canada and confirm the existence of these difficulties in predicting solutions to Canadian constitutional questions.

The immediate problems fall into two main fields, that of transportation or pipelines, and that of interprovincial and intraprovincial prorationing. Although the constitutional bases may come under different headings of the British North America Act, 1867, the solutions in both situations seem the same. Consequently pipeline transportation is used as the example of the legal confusion facing the petroleum industry, and the remaining portion of this paper deals primarily with that subject.

Before considering in detail the solutions which are available to minimize or correct the present uncertainty in jurisdictional problems, it is well to remember that oil lines and gas lines, product lines, gathering lines, service lines and distribution lines all perform different functions.

\section{Oil Lines}

\section{Functions of Pipe Lines}

Essentially the oil transporter carries oil owned by others and delivers it to refiners. Oil is capable of being stored in tanks and is also capable of being carried by rail, truck and ship. It is usually sold on a

•D. E. Lewis, Q.C., Reglonal Solicltor, Impersal Oll LImited. 1 Hon. Vincent MaeDonald. Lestalatlve Power and the Suprome Court in the Fiftles
(1960). 10. 
short-term basis. Canadian oil faces competition from oil produced by other countries and Canadian oil transporters must compete with other forms of transportation. It should also be emphasized that the Canadian oil transporter, in practice, assumes the role of a common carrier. Finally, it must be emphasized that the pipe line carrier does not deliver the oil to the ultimate user. Because of competition and the common carrier concept, detailed control and regulation are not required in all phases of oil pipe line operations. Generally, regulation may be limited to such matters as injury to persons and property, expropriation, and franchise considerations to avoid the duplication of trunk line operations.

\section{Gas Lines}

The gas pipe line does not possess the flexibility of oil carriers. Gas cannot as yet be carried by rail, truck or ship, but, in limited situations, it can be stored in natural underground storage. Gas is essentially sold on a long-term basis by the producer and is delivered to the ultimate user entirely by pipe line. The gas pipe line transporter and its distributors must have the capacity to deliver the gas exactly when it is needed on any day. For this reason, the gas pipe line is not susceptible to common carrier status. Other reasons are that its design is very closely geared to the maximum daily requirements of all its customers, and the location of many of its facilities is determined by almost mathematical considerations to ensure delivery to customers as economically as possible. The gas transporter provides, in addition to transporting the commodity itself, the service of delivering the right quantity exactly when it is needed. He therefore usually owns the gas in the pipeline so as to be free at all times to deliver gas to whichever customer may need it at any particular instant. Gas transmission cannot ordinarily be allowed to suffer interruption of any significant duration. It is susceptible to control as a monopoly or semi-monopoly. These differences from an oil pipe line must be kept clearly in mind in considering the administrative problems which arise in connection with pipe lines. Generally, gas transportation and distribution are closely regulated and, it is submitted, rightly so.

\section{Gathering Lines}

Whether the Legislature or the Parliament of Canada has jurisdiction over oil gathering systems within a province is one of the most controversial of jurisdictional questions relating to pipe lines. The question was dealt with in the Westspur Application." In that case Trans Prairie Pipelines, a provincial company, had applied to the provincial regulatory body for a permit to construct a pipe line wholly within the province. At the same time Westspur Pipeline Company, a federally-incorporated company, launched its competing application before the federal Board of Transport Commissioners for a permit to extend its interprovincial line and to construct a pipe line serving the same area. In the result, the federal Board failed to meet or resolve this question of jurisdiction. Rather, the Board avoided the question by dismissing Westspur's application on the technical ground that a second line was not in the public interest. Far from clarifying the problem, this evasion complicated it 
further. The case of Westspur-Producers Pipe Line Application ${ }^{3}$ added to the confusion. In this case Westspur desired to divest itself of its oil gathering facilities situated wholly within a province. The question was whether, if it did so, Parliament would still retain jurisdiction over these facilities. The Board of Transport Commissioners held that these -facilities would still be within federal jurisdiction because Westspur, despite its loss of ownership, would still retain control over them as gathering lines for its trunk line. Further complicating the matter is the fact that provincial lines joined to interprovincial lines under federal jurisdiction has not led to claims for federal control of the provincial lines in other cases.

The possibility that physical interconnection coupled with common ownership or management may extend the jurisdiction of Parliament back to the wellhead is, of course, one of the unanswered questions. In Alberta the organization and status of the Alberta Gas Trunk Line Company raises the possibility that the effect both of common ownership, control and of connection may be circumvented, thereby clouding the issue further."

\section{Service Lines}

In contrast to gathering systems, service lines, which include flow lines (lines from the wellhead to the tank farm or point of delivery to the gathering system), gas lines for heaters, water lines, etc. are normally owned by the operator of the producing lands, and so far have been considered purely intraprovincial pipe lines. It could be that the connection of any of these to an inter-provincial line might bring them under Federal jurisdiction for the same reasons as have been discussed with respect to gathering lines. Consequently in considering a solution to the overall problems, such lines must be included.

\section{Distribution or Consumer Lines}

While it appears to be generally accepted that distribution or consumer lines should be under provincial jurisdiction, the effect of interconnection on the right of the province to regulate them arises where the sole source of supply is a long-distance interprovincial gas line. Another type of regulation requires consideration in this context. In some provinces franchises and distribution permits are conditioned on the inclusion in gas supply contracts made in other provinces of terms relating to price and duration of supply. Having to meet these requirements after prolonged negotiations have taken place spur oil company lawyers on to contemplate constitutional issues which might be raised.

\section{Conflict in Laws of General Application}

A permit to construct given by a federal regulatory body carries with it many rights which encroach upon matters usually within the sole jurisdiction of the provinces. There is the right to expropriate right-of-way; to cross municipal and provincial road allowances; to cross rivers and streams of which title to the beds are in the province; to cross provincial lands, including areas under timber license; the right to move heavy equipment on provincial roads; and the right to construct pipe lines and

\footnotetext{
3 (1957) 76 C.R.T.C. 158.

4 See p. 394, ante.

- See p. 400, ante.
} 
pipe line facilities at specified locations in a certain manner and according to certain specifications. The building of a pipe line also involves the extension of provincial and municipal services to provide water, public health, educational facilities, and road and electrical services.

It seems that a pipe line is subject to the laws of general application of each province, ${ }^{0}$ provided such laws do not frustrate or defeat the construction of an extra-provincial pipe line, or seriously impair its maintenance or operation.' In practice there is confusion as to the powers of various provincial regulatory bodies charged with matters such as the use of water resources, municipal planning, factory or plant inspection, fire prevention, workmen's compensation, hours of work, housing, boiler and pressure vessels, labour, public health, and control of traffic on highways through load limits. Most provincial statutes charging provincial regulatory bodies with provincial responsibility were not drawn with the extra-provincial pipe lines in mind, and the inspectors and other persons applying the legislation do not understand the fine points of the law.

\section{American Experience}

Experience in the United States suggests that regulation of natural gas prices in Canada will be beset with difficulties.

Underlying conflict in the United States over the jurisdiction of the Federal Power Commission under the Natural Gas Act of $1938^{\circ}$ is a contest over gas prices between eastern and northern consumers and southern and western producers.

The monopoly position of a natural gas company supplying domestic consumers led to utility-type regulation in the United States about the time of World War I. This legislation provided that a state utilities board would determine the rate base of the natural gas company, decide the rate of return to be allowed, and consequently fix consumer gas rates. If the state board had no control over the price paid for gas by the natural gas company, then the board experienced great difficulty in protecting the consumer against unreasonable or discriminatory prices, particularly where the natural gas company was associated with gas pipeline and producer companies through interlocking directorships. When the United States Supreme Court denied state utility boards jurisdiction over the price of gas delivered in interstate commerce in Missouri v. Kansas Gas Co. ${ }^{10}$ and therefore, over the price paid for gas by a utility company, there was agitation for regulation by a federal agency. This agitation resulted in the Natural Gas Act," "which gave jurisdiction to the Federal Power Commission over interstate sales and the transportation of gas for resale to gas utility companies. At this stage the Federal Power Commission controlled the price of gas sold to the gas utility companies, and the state utility boards controlled gas prices to consumers. This system of regulation was complete where the pipeline company was selling gas from its own properties to the gas utility companies, because the price of this gas was included in the rate base allowed the pipeline company by the Federal

- See Laskin, Canadian Constitutional Law. 475, also C.P.R. v. Corp. of Notre Dame DeBonsecours [1899] A.C. 367.

i Campbell-Bennett Ltd. v. Comstock Midwestern Ltd. (1954) S.C.R. 207.

- I am Indebted to Professor A. R. Thompson of the Faculty of Law, University of Alberta for this part on Americon experience.

D 52 Stat. 821 (1938).

11 ) 265 U.S. 208 (1924)

il supra, n. 9 . 
Power Commission (see the Hope Case ${ }^{22}$ ). But if the pipeline company bought its gas from an independent producer, then this regulation was incomplete unless the price paid for gas to the independent producer was also regulated. The authority of the Federal Power Commission to carry out such regulation was not recognized until the Phillips Case in 1954."3

The pipeline companies objected to Federal Power Commission regulation of their gas-producing properties on a utility basis because the ratebase approach of determining "original cost" of the properties penalized the successful operator whose investment in providing gas reserves was low. Also, the rate of return approach did not take into account the highly speculative nature of gas exploration and production (see the Hope Case) ${ }^{14}$ To avoid this regulation, the pipeline companies, where possible, sold their producing properties and contracted with independent producers for their gas supplies.

The Federal Power Commission did not at first regulate these contracts because it was thought that the board's jurisdiction under the Natural Gas Act" did not extend to the regulation of producers, or to producer sales to pipeline companies. After the war, as pipelines rapidly increased in number and size, there was a scramble to contract for gas reserves. Favoured nation and escalator clauses had the effect of spreading each newly-negotiated price throughout the producing fields, and the "pricespiral" became the complaint of state utility boards who were trying to keep consumer prices in line. In 1947 consumption was 4,427 billion cu. ft. In 1961 it was 13,082 billion cu. $\mathrm{ft}$. The average wellhead price in 1947 was 6.0 cents per mef. In 1961 it was 15.1 cents per mcf., and rising at the rate of approximately 1 cent per mcf. per year. Consumer prices in New York had risen from 79.5 cents per mcf. in 1947 to 164.5 cents per mcf. in 1961. In the Phillips Case's the New York and other eastern utilities boards, as intervenants, challenged the immunity of independent contractors from sales regulation and the Supreme Court upheld their viewpoint. The Court concluded that the exception from regulation in $\S 1$ of the Natural Gas Act"i covered the physical facilities of production only, and not the sale by the producer for resale in interstate commerce.

The Federal Power Commission then found its facilities overwhelmed with hundreds of proceedings to regulate the prices to be paid to gas producers. Its first efforts to curtail spiralling prices were held valid in $C A T C O^{18}$ where the Supreme Court upheld the contention of the Federal Power Commission that in the case of initial rate proceedings under $\$ 7$ of the Natural Gas Act the Commission could condition certificates at price levels lower than those proposed without first holding a rate hearing. This decision had the effect of placing a producer under the onus of applying for rate increases under $\S 4$ of the Natural Gas Act and of carrying the burden of proof in such a hearing, with an interim increase granted only under a bond by the producer guaranteeing reimbursement to the consumer if the increase should not be confirmed. In 1961 the Federal Power Commission announced Statement of General Policy No.

12320 U.S. 591 (1944).

13347 U.S. 672 (1954):

14 sumra, n. 12.

15 Suma, n. 9.

16 Supra, n. 13.

18360 U.'s. 378 
61-1, whereby the Commission published a schedule of well-head prices for the different producing areas and declared that these price levels were "for the purpose of guidance and initial action by the Commission", and that future price-hearings would be enlarged to area-price hearings. If this area-pricing scheme is carried through, the result will approximate the type of price-control administered by the Wartime Prices and Trade Board in Canada during the war. Court actions challenging its validity are now in progress.

In 1963, the United States Supreme Court continued its emasculation of state authority over natural gas production by deciding in Northern Natural Gas v. State Corporation Commission of Kansas ${ }^{10}$ that a Kansas statute requiring an interstate pipeline company to purchase gas rateably from all producers in a field was an infringement of the regulatory powers of the Federal Power Commission under the Natural Gas Act and hence unconstitutional. Oil lawyers in the United States are apprehensive that this decision will set off further contests between state and federal authorities over the regulation of natural gas production, and that oil production will be indirectly affected. Some make dire predictions that the entire conservation and prorationing system is threatened.

These difficulties in regulation of natural gas are undoubtedly injuring the natural gas industry in the United States, and creating strains in the body politic-particularly because the conflict is somewhat regional in nature; south and west v, east and north. Even the economics of such regulation are in dispute (see Neuner, the Natural Gas Industry, (1960) Univ. of Oklahoma Press), and only time will tell whether the public interest is being advanced by the enlargement of federal regulation to include sales by independent producers.

Are similar difficulties to be encountered in Canada? There is the same regional conflict over natural gas prices between western producers and eastern consumers. There is the some local utility regulation, with gas utility companies in Ontario and Quebec being regulated in the supply of gas to domestic consumers by provincial utilities boards. The National Energy Board is a federal agency corresponding to the Federal Power Commission. All the features of the controversy are present. But there is one significant difference. Under s. 61 of the National Energy Board Act, $1959,,^{\circ}$ it is provided that:

61. Where the gas transmitted by the company through its pipe line is the property of the company, the differential between the cost to the company of the gas at the point where it enters its pipe line and the amount for which the gas is sold by the company shall, for the purposes of this Part, be deemed to be a toll charged by the company to the purchaser for the transmission thereof.

This section probably excludes from tolls the prices paid for gas entering interpro:incial pipelines, and therefore withholds from the National Energy Board jurisdiction to regulate producer prices. At any rate, to date the Board is not regulating producer prices, and the position in Canada corresponds to the United States position prior to the Phillips ${ }^{21}$ decision in 1954.

1983 Sup. Ct. Reporter G45 (1963).

201959 Can. c. 46.

21 Supra, n. 13. 
Has the Canadian producer any justification for believing that the tide of regulation which rolled over the producer in the United States will not roll over him? Politically speaking, the tide certainly can rise in predominantly consumer eastern Canada. It will be difficult for a federal government to resist an aroused eastern sentiment to regulate producer prices.

Constitutionally, there seems to be no obstacle to an amendment by Parliament of s. 61 of the National Energy Board Act, so as to confer on the National Energy Board jurisdiction to regulate the prices to be paid to producers for gas to be carried in interprovincial pipelines.

Examining the question on its merits, how should it be resolved? Will the public interest (in this case, a predominantly consumer interest) require regulation by the National Energy Board of prices paid to producers for gas? The answer should lie in the economics of competition. If competition can restrain the consumer prices of natural gas in Eastern Canada (apart from normal inflationary adjustments), at the levels which now prevail, and which presumably are acceptable since gas is displacing other fuels in the domestic market, then the eastern consumer is not likely to complain. While other fuels provide this competition at the beginning when gas must displace them to establish a market, experience in the United States shows that the competition of other fuels is ineffective once the consumer market for gas is established. The reason for the impotence of this competition is that the non-price advantages of gas as a domestic fuel usually outweigh price differentials, particularly once the cost of converting to gas has been expended.

Competition from United States gas supplies may hold Canadian producer prices in line. There is some flexibility in pipeline supply. In Ontario Consumer Gas has pipeline connections with United States pipeline companies. However, the export of United States gas requires certification by the Federal Power Commission and the threat of switching from Canadian supplies of gas to United States supplies might not be too convincing.

The economic considerations which suggest that eastern consumers are not likely to clamour too insistently for regulation of producer prices embrace the Canadian natural gas industry as a whole. The economic feature of this industry is that western Canada has vast reserves of gas which will more than meet Canadian requirements for many years to come. It is suggested that the effect will be to keep prices down. This condition of over-supply will be altered only to the extent that Canadian gas is permitted to enter the United States market. It can enter this market only under gas supply contracts that are regulated by the Federal Power Commission. In consequence, it is submitted that the pricing of Canadian gas will in large measure reflect the regulatory efforts of the Federal Power Commission. As is so often the case, Canadians have a direct stake in the dynamics of the United States market place, and eastern consumers in Canada can look to the Federal Power Commission to keep gas prices in line. However, the success of the Federal Power Commission in establishing workable regulatory systems for natural gas is by no means assured. Hence, consumers and producers in Canada 
should follow the vicissitudes of the Federal Power Commission and the Natural Gas Act with close attention. ${ }^{22}$

\section{Solutrons}

In addition to discussion of the general powers of the Parliament of Canada and of the provincial legislatures over transportation facilities and prorationing, some of the ancillary problems of jurisdiction in fields such as labour, workmen's compensation, taxation, etc., are worthy of comment.

\section{Declaratory Power, s. 99 (10) (c) British North America Act."3}

Any change in the American supply picture and its need for imports of both oil and gas can seriously affect the Canadian price structure. The influence of orders and regulations of the Federal Power Commission has been briefly discussed. In view of the impact of the international market on the industry and the conflicts that can arise between the western producer and the eastern consumer, it is not inconceivable that Parliament will act under the far-reaching power conferred upon it by s. 92 (10) (c) of the British North America Act, 1867. This section reads as follows:

92. In each Province the Legislature may exclusively make Laws in relation to Matters coming within the Classes of Subjects next hereinafter enumerated; that is to say,-

10. Local Works and Undertakings other than such as are of the following Classes:-

(c) Such Works as, although wholly situate within the Province, are before or after their Execution declared by the Parliament of Canada to be for the general advantage of Canada or for the advantage of two or more of the Provinces.

Parliament is the sole judge of the advisability of making this declaration and it is a matter of policy which it alone can decide. When the power is exercised, it vests in Parliament exclusive legislative authority over any local work thereby removing it from the provincial to the federal field of jurisdiction. Elevators and mills have been declared without constitutional challenge as to the classification. Railways have similarly been brought within federal jurisdiction.

If such a declaration is made then it seems clear that the federal authorities would have complete control over all phases of pipe line communicaiton, over pricing down to the well head, and over structures and all producing and distributing facilities. Such a policy decision is one which the oil and gas industry under present practices would not support too strongly.

Assuming Parliament were to declare the oil and gas producing and transportation industry, or part of it, to be for the general advantage of Canada, many interesting questions would then arise as to how far the power operates. For instance, the broad powers may not affect independent isolated wells or pipe lines within a province, where the pro-

22 For further discussion, see:

The Independent Producer and The Federal Power Commisston, 6th Annual Institute. p. 1: Production, Transportation, Sale of Gas, 8th Annual Instltute: Federal Regulation of Gas Producers, Rocky Mountain Mineral Law Institute, (5th Annual), p. 193; SullIvan's Handbook of Oll \& Gas Law, p. 470.

291867 (Imp.) 30-31 Viet. c. 3. 
duct carried is used nearby or only within the province, ${ }^{24}$ and the line has no connection with nor abuts another province.

Similarly, the fact that the Crown in the right of the province is the lessor, and in some instances, the owner of the majority of oil and gas rights in the province, raises problems that may not be solved by a declaration under s. 92(10) (c). The contractual rights of the owner and producer respecting such matters as limitations of production and export probably have some bearing.

In the result it is submitted that a declaration under $92(10)$ (c) by Parliament is not an ideal solution, for it raises many other problems that may be just as difficult to decide as those presently in existence.

\section{Submission to the Courts}

As problems arise they could be dealt with by the courts. This approach has the limitation that each case or reference depends on its own particular facts and therefore the decision could be limited in scope and not necessarily of general application. The Honourable Vincent MacDonald, on pages 24-25 of his lecture, ${ }^{2 \pi}$. had this to say on the question of references:

In many of the cases the Judges obviously felt embarrassed by the Terms of Reference or the matters recited therein and above all, by the absence of such concrete evidence as would be before them in ordinary litigation. It is clear that constitutional validity depends largely upon the actual or contemplated effect of legislation upon the relevant context of affairs; and yet the required answers must be made in large ignorance of the facts on which the legislation operates, or legislation consequent on those answers will operate.

It is not surprising that answers based so largely on speculation, rather than experience, have often been conceptual in nature, or couched in such terms of assumption or qualification as to destroy much of their value as authorities. Yet authorities they remain in fact however limited in theory; for it is difficult for a Court to recede from solemn pronouncements so made. All these considerations have their echos in the References of this decade, and they recall various expressions of judicial aversion to this type of case, particularly where abstract questions are concerned.

This type of adjudication has also the disadvantage of requiring immediate declarations as to conclusions normally reached by gradual stages of evolution in relation to specific fact-situations. It may well be that in the matter of statutory validity "deliberate speed" is preferable to "majestic instancy". It would conduce to the orderly development of the law if this procedure should be restricted, in practice, to questions arising from the text of an Act or draft Bill.

Notwithstanding this criticism, the method is not to be dismissed completely, for it is submitted that a number of questions were answered successfully and guides for the future given in the Farm Products Marketing Reference. ${ }^{26}$ Here the Supreme Court of Canada was faced with eight very detailed questions as to the validity of parts of the Ontario Hog Marketing Act and orders and regulations made under it. In a similar way the framers of Acts dealing with oil and gas transportation or control might get valuable aid by skillfully drawn references.

2+ For further discussion on this subject see:

Laskin Canadian Constitutional Law, 497 (2nd Ed.); Hon. Vincent C. MacDonald - Parliamentary Jurisdiction by Declaration, (1934), 1 D.L.R. 1; S.M.T. Eastern V. Ruch, [1910) 1 D.L.R. 190, where the Trlal Division of the New Brunswick Court held that a provinclal highway is not a work or undertaking connecting two provinces and therefore within Dominion jurisdiction simply because it abuts on a hikhway of another province. 28 Supra, n. 1.

20 Farm Products Marketing Roforence [1957] S.C.R. 198. 


\section{Amendment of the Constitution}

From a purely legal point of view, an amendment to the British North America Act more clearly defining federal and provincial jurisdiction with respect to pipe lines could be the ideal solution. However, the practical difficulty of obtaining even minor constitutional amendments on relatively non-controversial matters probably rules this method out. When more cooperative experience in regulation has been gained, this approach may become more appropriate. For instance, an amendment might enable delegation to, and from, Parliament and the legislatures. The principle of delegation found much favour with the Dominion-Provincial Conference of 1950, and future experience might show its practicability.

\section{Cooperation Between Provincial and Federal Authorities}

It is submitted that the most practical proposals which can be made at the present time fall within the realm of cooperation between provincial and federal authorities.

While it is recognized that regional variations will inevitably be encountered and that it will be impossible to reach complete agreement on all subjects, one of the first objectives should be to reduce duplication of costs in administration and services. This reduction could be facilitated by delegating the right of inspection of construction and maintenance operations for all pipe lines to provincial inspectors, exchanging information between government departments and regulatory boards, and by requiring common records and accounting practices. Statistical and other data requests should not be duplicated.

However, in the broad field, the most serious administrative problem facing the pipe line industry is the question of control of the gathering .and local oil or gas lines which connect with an extra-provincial system. It seems to be the consensus of opinion of producers that gathering systems and service lines wholly within a province are best regulated by the province. Such regulation probably could be achieved by a delegation of authority to a board by both the federal and provincial governments in the same way that delegation now exists under the federal Motor Vehicle Transport Act of 1954. This Act is a consequence of the decision in the

\section{Winner case. ${ }^{27}$}

In that case a United States company operated a public bus system between Boston and Halifax. The New Brunswick provincial Board granted the company the right to operate over its roads but not the right to enbus or debus passengers within New Brunswick. The company refused to be bound by the restriction and an injunction was sought. The Privy Council held that the undertaking could not be divided into areas, that it was one, indivisible undertaking extending beyond the province, and that therefore, it was solely within Parliament's jurisdiction to regulate. At the same time it was conceded that provincial legislation regulating highway traffic would apply to such an undertaking. To provide a uniform system of regulation Parliament enacted the Motor Vehicle Transport Act As $^{8}$ to give provincial licencing boards power to licence extra-provincial motor carriers operating in the provinces and to

27 Winner y. S.M.T. (Eastern) Ltd. and A.-G. Can. [1951] S.C.R. 887. See also Ballem, 32 Can. B. J. 788: MeWhinney, 30 Can. B. J. 832.

28 Can. 1954, c. 58. 
regulate tolls, etc. By this means, one board in each province, as both the federal and provincial delegate, carries out a comprehensive system of regulation of the entire motor vehicle transport industry.

In another case, the Potato Marketing Reference, ${ }^{20}$ the Agricultural Products Marketing Act:" (Prince Edward Island) provided for the establishment of schemes for the marketing of natural products and of boards to administer such schemes. A board was set up and given powers to regulate the marketing of potatoes within the province. Parliament passed the Agricultural Products Marketing Act ${ }^{31}$ authorizing the Governor-General in Council to delegate to marketing boards established by the provinces the power to regulate interprovincial and export trade. A delegation of power under the Act was made to the Prince Edward Island Board to regulate interprovincial and export trade in the Island's potatoes. The Board made orders under this power and the Supreme Court of Canada upheld this technique of delegation.

The result of these cases is to provide a practical method whereby powers granted either to Parliament or to provincial legislatures may be exercised by a common agency when direct delegation is forbidden. ${ }^{32}$

\section{Agreement Between Parliament and Legislatures}

It has been suggested that delegation of authority need not be the only medium of cooperation, but that solutions could be arrived at by tacit agreement between Parliament and the legislatures. The late C. D. Howe, during the last Liberal regime, seemed partial to such an understanding. He intimated that the federal authorities had no real desire to control gathering lines or product prices within the province. In result there existed a tacit agreement whereby no government action was taken at any level to upset the existing arrangements. However, such undertakings cannot give any real assurance of continued armistice, for they can be upset by attack from unexpected sources. For example, a farmer annoyed at expropriation of a right-of-way might attack the legislation. It is suggested that American experience is also a deterrent against following such a procedure. There the gas industry and Congress thought that the Natural Gas Act clearly divided the power of regulation between the state and federal authorities, but, as has been shown, the Supreme Court of the United States interpreted the statute to give federal control over wellhead prices, to the consternation of all parties. This situation could easily be repeated in Canada and consequently it is submitted that the delegation method offers the best prospects for practical solutions. But that is not to say that the tacit agreement method should not be used at all. It could well provide workable arrangements in some of the ancillary cases such as safety inspection, statistics, labour problems and the like.

\section{Vehicles of Discussion and Recommendation}

In a consideration of how such co-operation or delegation can be accomplished, there are a number of avenues open. The Federal-Provincial Conferences provide a forum where firm recommendations can be considered, but a drawback is that there is no provision for proper industry

20 [1952] 2 S.C.R. 392.

30 P.E.I. 1940 , c. 40 .

31 Can. 1949, $18 t$ Sess. c. 16.

s2 Nova Scatia Delegation Reference [1951] S.C.R. 31. 
representation. However, the Conference could establish a committee with industry representation to study the problems and make representations.

The Mines Ministers Conference may be influential. This group consists primarily of the Ministers of Mines and their deputies for each of the Provinces together with their counterparts for Canada as interested observers. The Conference is broken down into committees dealing with the various mineral substances and ancillary problems. Petroleum and natural gas comes under a committee of that name. This committee consists of a number of senior administrators in the Departments of Nines, a number of senior officials in the oil and gas industry, senior representatives of the Federal government interested in mines, and representatives of other provincial departments affected by decisions of the group, such as the Energy Department in Ontario.

Sub-committees or working groups of this committee consider common problems and draft model Acts, regulations or directives. Their proposals are relayed to the Ministers of Mines who may approve or refer the recommendations for further study. If the Mines Ministers group could come to agreement on a subject such as delegation, a long way towards final settlement between Ottawa and the provinces would be achieved, because the subject would already have been thoroughly discussed by industry representatives and by provincial and federal civil servants. It should be added that nearly all of the industry representatives on the Oil and Gas Committee and on its working sub-committees are nominees of or approved by the Canadian Petroleum Association, the Independent Petroleum Association of Canada, the Canadian Gas Association or the gas and petroleum associations of Ontario. These bodies, themselves, have a role to play in initiating proposals for cooperation between federal and provincial authorities.

It is submitted that proposed co-operative steps must be representative of the oil and gas industry both on the national and the provincial levels. There have been times when a national group has forgotten problems at the provincial level, and vice-versa, in requesting legislation. Nor can the consumer be forgotten. Particularly in the gas field, because of its quasi-monopolistic position, provision must be made for consumer representation.

\section{Conclusion}

The purpose of this paper has been served if it has opened ground and given directions which will lead to practical solutions of the constitutional problems facing the oil and gas industry. 